\title{
暗順応初期の視認時間に及ほす心身負荷の影響
}

一測定器の試作——

藤 井 真 美*

（昭和50年 4 月24日 受付）

\section{Effect of Physical and Mental Burden on Elapsed Time of Visual Perception in the Initial Stage of Dark Adaptation: measurement with a new device}

\author{
Shinmi Fujii \\ (Faculty of Education, Gifu University)
}

It is known that visual perception in the dark is different according to conditions of environment and to the individual visual acuity, and also known that it is influenced by certain disease, fatigue and alcohol ingestion even within the same individual.

It may, therefore, be possible to determine the event of lowering of the physical and mental functions by means of measuring the elapsed time of visual perception in the initial stage of dark adaptation. For this purpose an instrument equipped with an electronic timer was developed, by which the restoration time of the visual perception under a low illumination ( 5 lux ) preceded by a 5 seconds' exposure in a high illumination ( 3000 lux) could be measured precisely.

In the present study an outline of the instrument and a few data on basic experiments were described. It was suggested that the obtained values by this method were closely related to the extent of lowering of physical and mental functions.

(Shinmi Fujii: Effect of Physical and Mental Burden on Elapsed Time of Visual Perception in the Initial Stage of Dark Adaptation: measurement with a new device, Jap. J. Phys. Educ., Vol. 22, No. 1, May, 1977, pp. 19 25)

\section{1. 㒂票}

暗順応に関する研究は，基礎医学の分野では， 錐体と桿体の機能に関する研究や，視紅（rhodopsin）の腿色・合成に関する研究，むるいは暗順 态経過に関寸る視覚生理の研究が多く, ${ }^{8)}$ 一方, 臨床㭱学の分野では，先天性・後天性の夜盲症に
よる光覚障害に関する研究が数多く見られる.

しかしながら，生体に負荷を与えて，照度低下 時に和ける暗順応初期の視認時間から心身機能へ の影響度を検索しょ5とする研究はほとんどなく 筆者の知るところでは，暗順応曲線に影響を及ぼ す要因として，疲学や不眠があげられている8 すぎない状態である。 
生体は，恒常性によって機能の変化をできるだ け少なくしょうとする特性をすっているが，その 中で变化を追求しなければならないところに疲労 研究の困難性がある，と大島 ${ }^{5,10)}$ (1960）方指摘 したよ5に，生体は種々の負荷を受けても，恒常 性を維持しょうとする傾向が強いために，機能の 変化が現われにくく，現われても時間の経過とと もに元の状態にもどりやすいものである。

そこで，従来広く行われている生理学的疲学検 查が，機能の変化の状態を捉えることに主眼をお く傾向の強いことに注目し，このような機能変化 を時間の関数として招える方法を検討した。

この方法は，負荷前の機能に比べて負荷後の心 身の機能がどれほど低下したかを，低照度環境に 曝したときの視認時間の遅れ，ないし行復のしか たから調べようとするもので，本稿では，試作し た視認時間測定器について, 試作に至る経過, 測 定器の構造・機能，並びに測定に関する基礎的尖 験について報告する。

\section{2. 試作に至る柽過}

時間的要素に基つくく機能検查には，止息時間， 眼調節時間, 反応時䦭，㭙間再生，認知時間， ${ }^{5)}$ 眩惑回復時間などの諸検查法があるが，筆者も簡 易な測定器を試作して，遠近調節時間と暗順応初 期の視認時間を测定し，この測定器では, 負荷後 の機能低下が，調節時間の延長よりも暗所での視 認の遅れに現われやすいことを確めた. ${ }^{1}$ この簡 易測定器は, 視標が大きく, 視標の呈示方法が手 動であるなど，機能面に問題があったけれども， このよ5な手製の測定器でさ克, 視認時間の速さ から機能低下の度合を知る手がかりを光たこと は,一つの収獲であったといえる。

このことから, 測定器の機能を, 明から暗, あ るいは暗から明に変化したときの視認時間を测定 するだけとし，器械の自動化と精密化によって精 度が高められれば，負荷による心身機能への影響 を量的に捉えることができるのではないかという 伋説を立てた。

人間は，急激に低照度環境に懪されると，初め の5ちは暗さに順応でさないけれども，やがて周 囲の視対象が徐々に見觉始め，調節によって形な
どが明視できるようになる。

低照度下での視認の速さは, 測定前の照射罢境 （以下前照射環境と略す）や暗所の照度などによ っても異なるが，環境を一定にした場合でも個人 差があり，同一個人においても一様ではない。た と艺，視力差，年齢，眼疶の有無などは個人差 の形成要因となり，心身の疲労，睡眠不足，飲酒 などの場合は同一個人であっても生理機能に変化 を示し，これが視諗時間の遅れに現われる. ${ }^{11}$

このことから，視力差が測定值に影響しないす 法をとれば，視力の良否にかかわらず測定できる し，また，負荷量の程度に応じて，暗所での視認

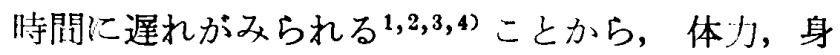
体的・精神的作業適性，あるいは披学など量的 に測定することも不可能ではないと考える。

もとより，急激に変化した瑻境に適応する機能 は，体調のよい無負荷安静時が最も俴れている。 したがって，低照度環境に曝され心ときの視認時 間を測定すれば，無負荷時には速く，会荷後には 遅くなる。そして，無負荷洔の視認時間を事前值 とし，目荷後の視認時間を事後值とすれば，変動 率から機能の低下度を推定することができ，無任

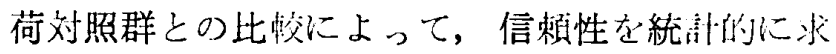
めることも可能となる.

本測定器は，このような考え方を根拠にして設 垶したもので, 機器は八神理化器製作所の技術に よって完成した。

\section{3. 測定器の粠造・機能}

測定器は，本体と操作器からできている。 〈A体〉（㲸 1 )

(1)は被検者が視標を視認したとき值ちに応答す るためのスイッチで，これを押寸と低照度ランプ Aが消えて時計が停止するようにできており，手 もとの適所へ移動できる。

(2)ののそき空には，闻眼視ができる大きさの空 があり，透明ガラスによって機器の内外が遮断さ れ，外界の光線が両眼の周囲から内部へ投射しな いように作られている.

(3)の高照度ランプ Aは，低照度視標に切り替え るまでの一定時間（0〜60秒の間で任意の時間に セットできる）被検者の視野を高照度下におくた 

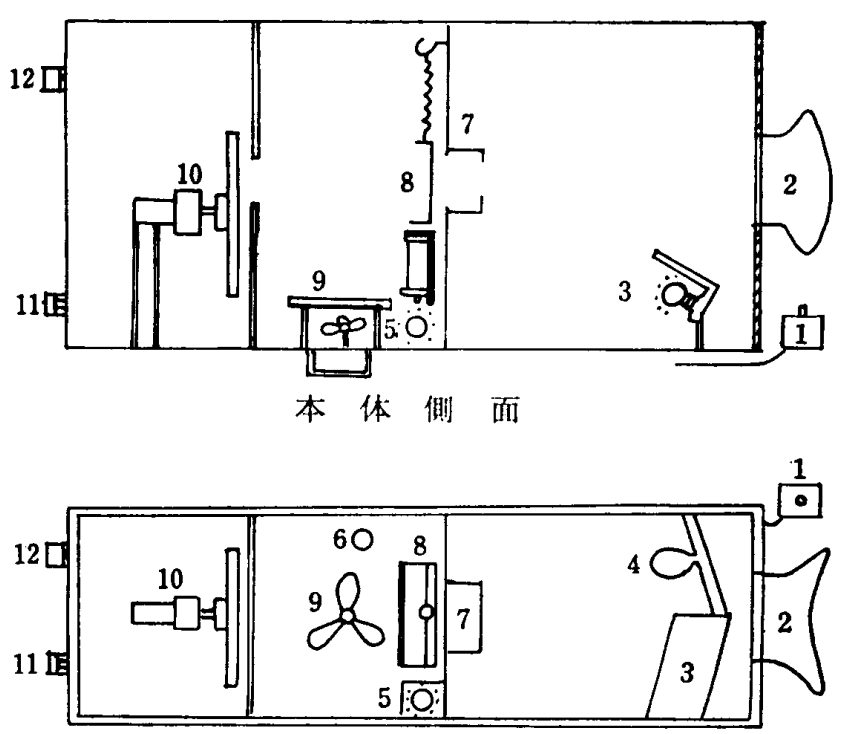

本 体上面

図 1 視認時間测定器の本体
1. 応答スイッチ
7. 残光遮蔽枠
2. のぞき空
8. 電磁遮蔽装置
3. 高照度ランプA
9. 冷却装置
4. 低照度ランプ $\mathrm{A}$
10. 視標回転装置
5. 高照度ランプ $\mathrm{B}$
11. 同上電源コード
6. 低照度ランプ $\mathrm{B}$
12. 照度調節つまみ

めの照明である.

(4)の低照度ランプ $\mathrm{A} は ，$ 明順応初期の視認時間 を測定するとき，高照度視標に切り替兄る前の一 定時間，被検者の視野を低照度下におくための照 明である。

(5)，明順応初期の視認時䦭を测定するときの 高照度ランプB（約 $3000 \mathrm{lux}$ ) で, 光源からの光 が直接眼に入らないょ5にできている。なお，暗 箱内部は黒く塗って反射率を小さくした。

(6)の低照度ランプ Bは，暗順応初期の視認時間 忞測定する際の照明で，(12)の照度調節つまみによ って，視標面照度を 1〜10 lux の䦎で任意に調簀 できるようにした。

(7)の残光遮蔽枠は, (3)の高照度ランプ Aが消え るときに生ずる残光が視標に投射しないよ5にし たものである。

(8)の電磁遮蔽装置は，スタートスイッチを入れ ると，予めセットしたタイマーによって自動的に 高照度ランプが消光, 同時に電磁装置により遮蔽 板が上挙して，低照度視標が呈示されるよ5にで きている．次に，被検者の視認により态答スイッ チが押されると, 低照度ランプが消えて遮蔽板が
下がり，視標が見えなくなる。

(9)の冷却装置により，暗箱内の温度が高温にな ると，自動的にファンが回転し，暗箱内の空気を 排出して内部を冷却する.

(10の視標回転装置は，アルミ箔にランドルト環 をプリントした回転板と，これを回転させる電磁 回転装置によって視標が目動的に呈示できるよう に作られている.

(11は操作器に接続された連結コードと電源コー ドで，(12)は照度調節つまみである。

<操作器> (间 2 )

(1)の電源スイッチをONにして，(2)のパロッ トランプが点灯したかどらかを確める. 次に, (3) の明・暗切替スイッチを暗の方向へ入れ，(4)のタ イマーを 5 秒の目盛に合わせる.ささらに予備操作 として，(5)の視標選択スイッチを回して低照度下 (5lux) で測定した 1 分後の視力（以下夜間視力 とい5）より1段階大きい視標を呈示し，この指 標の方向を呼称させて，6の視標確認装置によ り，被検者が指標を正しく視認しうることを確め ておく。

視標は視力0.1〜1.5までの12種類で，各種類と も上下左有の方向を変えたランドルト環を 3 個ず

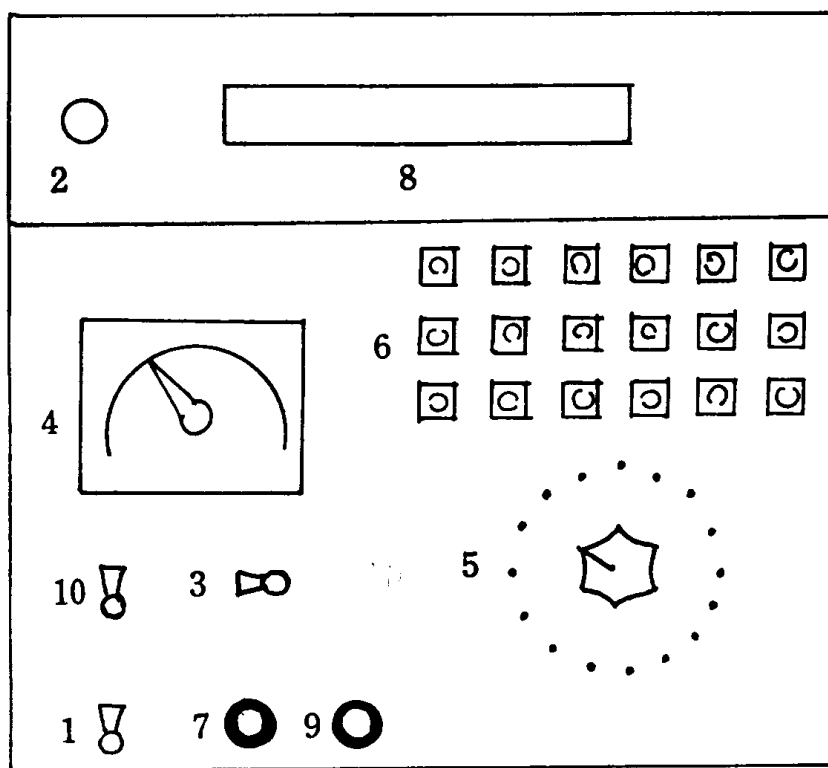

図 2 操作器
1. 電源スイッチ
6. 視標確認装置
2. パイロットランプ
7. スタートスイッチ
3. 明・暗切筸スイッチ
8. 電子時計
4. タイマー
9.リ七ットスイッチ
5. 視標選択スイッチ
10. 照度切替スイッチ 
つ貼付した。

このよ5にして(7)のスタートスイッチを押す と，本体（図 1） (3)の高照度ランプ A と本体(6)の 低照度ランプ Bが点灯し， 5 秒後には，本体(3)の 高照度ランプ Aが消灯するとともに電子時計が作 動し，同時に本体(8)の電磁遮蔽装置が上挙して視 標が呈示される。やがて被検者は徐々に低炤度視 栖が兒えてくるので， ランドルト懪の方向が視認 できたら直ちに手もとの忘答スイッチを押し，口 答で上下左右の方向を国答する，忘答スイッチが 押されると電子時計が停止するので，検者は低照 度下に曝されてからランドルト薪を視認するまで の時間を正確に测定することができる。

なお， 1 回の测定值は，5回の視認時間を平均 したものであるが，本椧查法は事前值が負荷後の 変化を知るための基準となるので，測定に際して は十分な練習を行い，测定值の上限と下限との差 が 1 秒以内になるよ5留意した。

\section{4. 測定に関する基礶的英験}

<実験 1> 暗順応初期の視認時閌正常值

目的 安静正常状態における暗順応初期の視認 時間を知るため，次の実験を行った。

方法 男子37名，女子115名，計152名の大学生 （18〜25歳）を対象にして，昭和47年11月に，本 測定器を用いて，低照度環境に曝したときの暗順 态初期の視認時間を测定した。

結果およひ考寀 暗順态初期の視認時間は，男 子が平均 2.554 秒，女子 2.643 秒を示し，男女の間に 有意な差は認められなかった。な打，全員の平均 は2.631士0.908秒であった。この湘定により，初 めての被検者にも実施できることが確められた。 また，液間視力と同一大の視標を用いたことと， 測定の熟練度などから，視認時間に若干の遅れが みられた。

<夾験 2> 暗順応初期の視認時間に含まれる 要素別所要時間

目的 暗順応初期の視認時間には，初期暗順応 時間, 調節時間, 反応時間の 3 要素が含まれる. これらの要素別所要時間は，視標の大きさや視標 面照度などの違いによって割合が変わるので，基 準值を求めることは困難であるが，本実験の本質
を明らかにする5えで必要と考古，次のよ5な実 験を行った。

万法 大学生10名の被検者（19２2歳）に対し て, 安静正常状態での視認時閂，反応時間，およ び，何かがあると感知するまでの時䦗をおのおの 5 [回测定し，それぞれの平均值を個人の測定值と

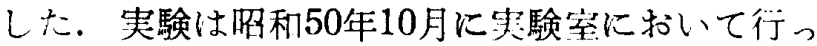
た。

初期暗順応時閂䧇，低照度視標に替わってから 視標の存在を感知してスイッチを押すまでの時間 を测定し，この值から反心時間を差し引いたもの である。また，調節時間は，視標の存在を感知し てから視標の才问を視認するまでの時間とし，視 認時間から初期暗順応時間と反応時間を差し引い て求めたものである.

さらに反応特間は，本測定器により，低照度照 明に替わったら押すとい5オ法で測定した。

結果および考樌 これにより，本測定法では，急 に低照度環境に曝されると，初期暗順応をするま では何も見壳ないこと，視標な明視するまでの調 節には最も長い時間を姴し，調節時閶は視標が小 さいと延長することなどが確められた。

表 1 照度低下時に敌ける視認時間と要素别所要時 間

$(\mathrm{sec})$

\begin{tabular}{|c|c|c|c|c|c|}
\hline 視標 & \begin{tabular}{|} 
被検 \\
者数
\end{tabular} & 視認時間 & $\begin{array}{l}\text { 初期暗順 } \\
\text { 応 時間 }\end{array}$ & 調節時間 & 反応時間 \\
\hline A & 10 & $\begin{array}{r}1.563 \\
\pm 0.376\end{array}$ & $\begin{array}{r}0.420 \\
\pm 0.072\end{array}$ & $\begin{array}{r}0.808 \\
\pm 0.342\end{array}$ & \multirow{2}{*}{$\begin{array}{r}0.335 \\
+0.055\end{array}$} \\
\hline B & 10 & $\begin{array}{r}2.001 \\
+0.539\end{array}$ & $\begin{array}{r}0.431 \\
\pm 0.062\end{array}$ & $\begin{array}{r}1.235 \\
+0.532\end{array}$ & \\
\hline $\begin{array}{c}A z \\
t\end{array}$ & & $\begin{array}{l}t=1.998 \\
p<0.1\end{array}$ & $\begin{array}{l}t=0.301 \\
p<0.8\end{array}$ & $\begin{array}{l}t=2.029 \\
p<0.1\end{array}$ & \\
\hline
\end{tabular}

（注）視標 $\mathrm{A}$ ：夜間視力上り 1段階大きい視標 視標 $B$ ：夜閴視力と同じ大きさの視標

また, 反芯時間では, 测定器の構造上から,や や遅い值が得られた。これらの夷験により，初期暗

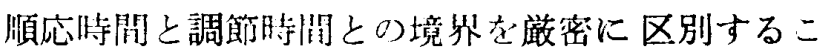
とはできないけれども，本実験で測定する視認時 間の大半は負荷による影響が最も現われやすい視 覚機能()で占められていることが確められた。

〈実験 3> 視標の明るさや大きさと視認時間

目的 視標面照度が明るいほど， あるいは視標 が大きいほど見やすいことは周知のとおりである 
がここのよなな視標の明るさや大小が視認時間に どの上ラな影響を及ばすかをみるため，次の実験 を行った。

方法 視標面照度之視認時閆については，大学 生10名の被検者（19２2歳）に対して，視標面照 度 3〜10lux まで6 段階の視認時間を測定した。

また，視標の大ささと視認時間については，大 学生12名（19 23歳）の被検者に対して, 視樈面 照度を５lux にしたときの各視標 $(0.2,0.4,0.6$ ， $0.8,1.0 の 5$ 種類）について視認時間を測 定し た。

結果およひ考察 この結果, 前者では,視標面照 度が低くなるほど視認時間とそのバラッキがとも に大きくなることが確められた。

表 2 視標面照度と視認時間 $(n=10)$

\begin{tabular}{|c|c|c|}
\hline $\begin{array}{l}\text { 視標面照度 } \\
\text { (lux) }\end{array}$ & $\begin{array}{c}\text { 視認時間 (sec) } \\
M \pm S D\end{array}$ & $\begin{array}{l}3 \operatorname{lux} \text { と各照 } \\
\text { 度との } \mathrm{t} \text { 検定 }\end{array}$ \\
\hline 3 & $3.396+1.303$ & \\
\hline 4 & $2.560 \div 1.305$ & $\begin{array}{l}\mathrm{t}=1.499 \\
\mathrm{p}<0.2\end{array}$ \\
\hline 5 & $2.101+0.842$ & $\begin{array}{l}t=2.505 \\
p<0.05\end{array}$ \\
\hline 6 & $1.781 \pm 0.647$ & $\begin{array}{l}\mathrm{t}=3.331 \\
\mathrm{p}<0.005\end{array}$ \\
\hline 7 & $1.670 \pm 0.600$ & $\begin{array}{l}t=3.609 \\
p<0.005\end{array}$ \\
\hline 10 & $1.416 \pm 0.519$ & $\begin{array}{l}\mathrm{t}=4.235 \\
\mathrm{p}<0.001\end{array}$ \\
\hline
\end{tabular}

表 3 視標の大きさと視認時間 $(n=12)$

\begin{tabular}{|c|c|c|c|}
\hline 視 標 & $\begin{array}{c}\text { 視認時間 (sec) } \\
M \pm S D\end{array}$ & 被検者数 & $\begin{array}{l}\text { 視標 } 0.2 \text { と } \\
\text { 各視標との } \\
\mathrm{t} \text { 検定 }\end{array}$ \\
\hline 0.2 & $1.21+0.47$ & 12 & \\
\hline 0.4 & $2.23+1.39$ & 12 & $\begin{array}{l}\mathrm{t}=2.306 \\
\mathrm{p}<0.05\end{array}$ \\
\hline 0.6 & $3.12+2.38$ & 9 & $\begin{array}{l}t=6.783 \\
p<0.001\end{array}$ \\
\hline 0.8 & $3.57+2.25$ & 8 & $\begin{array}{l}\mathrm{t}=2.640 \\
\mathrm{p}<0.01\end{array}$ \\
\hline 1.0 & $3.77 \cdot 1.68$ & 6 & $\begin{array}{l}\mathrm{t}=4.629 \\
\mathrm{p}<0.001\end{array}$ \\
\hline
\end{tabular}

また後者では，1.0の視標による視認時間は， 0.2 に比して約 3 倍の遅延を示し，視標が小さく なるはど視認が困難になることが確められた。

さらに，夜間視力の個人差により，0.2と0.4の 視標は全員が視認できたが，0.6では 9 人，0.8で は 8 人，1.0では 6 人が視認しえただけであった。 これらはすべて予想した結果であり，このことか
らも測定器の精度が高められたことがわかる。 <実験 4> 前照射䘫境之視認時間

目的 前照射環境亡しては，本测定器による高

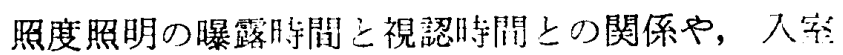
前の環境照度が問題となる。ここで，3000 lux の 高照度照明下に目を曝す時閒の長五之視認時閪之 の関係をみるために前者の笑験を，また，笑験空 へ入室する前の環境照度の逽いと視認時閆との関 係を調べるために後者の実験を行った。

万法 高照度照明の曝露時䦌上視認時間につい ては, 大学生（20－22歳）4名に対して，5秒前 位で30秒まで高照度下に曝露したときの視珰時間 を 5 回ずつ测定してその平均值を個人值とし，4 名の平均とその標準偏差を求め心。

また，宾外の環境照度と視認時間との関係につ いては，大学生（22歳） 3 名に刘して，1日目は 暗所と $200 \mathrm{lux} ， 2$ 日目は $2000 \mathrm{lux} と 6000 \mathrm{lux}$ の 4 照度下に，それぞれ30分閒安静状態で待機させ 犬後, 实駼䇪にもどして, 值後, 10分後, 20 分後, 30分後に暗順応初期の視認時間を测定し大。な お，この際の事前值は，それぞれの照度下に30分 開㴖在する前に，人宰後の10分閒を安静のまま待 機させてから测定したものである。

結果およひ考案 前者について或験した絬果, 表 4 の成績を得た。これによって,高照度曝露時聞 が長いほと， 視認時間が姃長することを確めた。

この結果は，実験方法は翼なるが，前照射時問 が長い汪と暗順态の阻害度が增すとい5齐藤 ${ }^{12)}$ 大島 ${ }^{11)}$ らの成績に近いものと考える。

本検查法で前照射時開を 5 秒とした理由は，前

表 4 高照度曝露時閪の長さと視認時閒 $(n=4)$

\begin{tabular}{|c|c|c|}
\hline $\begin{array}{c}\text { 懪露時䦎 } \\
(\mathbf{s e c})\end{array}$ & $\begin{array}{c}\text { 視認㸞間 } \\
\mathbf{M} \pm \mathbf{S D}\end{array}$ & $\begin{array}{l}\text { 高照度曝露前 } \\
\text { と曝露復との } \\
\mathrm{t} \text { 换足 }\end{array}$ \\
\hline 0 & $1.473: 0.137$ & \\
\hline 5 & $1.820: 0.047$ & $\begin{array}{l}t=3.086 \\
p<0.05\end{array}$ \\
\hline 10 & $2.108 \pm 0.105$ & $\begin{array}{l}\mathrm{t}=5.179 \\
\mathrm{p}<0.005\end{array}$ \\
\hline 15 & $2.738+0.480$ & $\begin{array}{l}\mathrm{t}=4.260 \\
\mathrm{p}<0.01\end{array}$ \\
\hline 20 & $3.809+1.142$ & $\begin{array}{l}t=3.582 \\
p<0.02\end{array}$ \\
\hline 25 & $4.486: 0.889$ & $\begin{array}{l}\mathrm{t}=4.335 \\
\mathrm{p}<0.05\end{array}$ \\
\hline 30 & $5.852-2.062$ & $\begin{array}{l}t=3.674 \\
\mathrm{p}<0.02\end{array}$ \\
\hline
\end{tabular}


麦 5 前照射環境の照度别視認時間 $(n=3)$

\begin{tabular}{c|c|c|c|c|c}
$\begin{array}{c}\text { 事 前 } \\
(\mathrm{sec})\end{array}$ & $\begin{array}{c}\text { 環境照度 } \\
(\text { lux }\end{array}$ & $\begin{array}{c}\text { 直 後 } \\
(\mathrm{sec})\end{array}$ & $\begin{array}{c}10 \text { 分後 } \\
(\mathrm{sec})\end{array}$ & $\begin{array}{c}20 \text { 分後 } \\
(\mathrm{sec})\end{array}$ & $\begin{array}{c}30 \text { 分後 } \\
(\mathrm{sec})\end{array}$ \\
\hline 1.52 & 0 & 1.43 & 1.45 & 1.46 & 1.38 \\
\hline 1.54 & 200 & 1.18 & 1.46 & 1.43 & 1.52 \\
\hline 1.89 & 2000 & 3.39 & 1.92 & 1.75 & 2.01 \\
\hline 1.74 & 6000 & 3.62 & 1.78 & 1.65 & 1.69 \\
\hline
\end{tabular}

（注）事前值を測定してから，各照度下に30分間滞在さ 世, 直後・10分後・20分後・30分後の 4 回测定し た.

照射がないと実験過程で暗順応が進行して 視認時 間が速まり，反対に前照射時間が長すぎると，こ れが負荷になって視恝時間が遅れるなどのためで あり,この程度の時間なら, 緊張の持続も負担に なるほどでないと考えたからである。

後者については表 5 の成績を得た。

これによって，環境照度が明るいほど実験室照 度にもどした直後の視認時間が延長するが，10分 後にはほほ事前值に近づくことが確められた。

〈実験 5> 本検查法の再現性について

目的 同一被検者に対して，同一条件のもとで 同一実験を 2 回行った場合, 1 回目と 2 回目の視 認時間に相関がみられれば，本検査法に再現性が あると考えて，次の実験を行った。

方法 安静正常状態における暗順応初期の視認 時間を测定してこれを事前值とし，時刻判読負荷

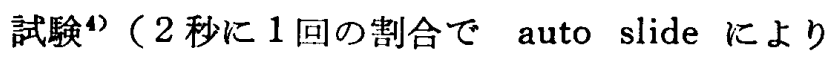

表 6 視認時間の再現性

\begin{tabular}{c|c|c}
\hline & \multicolumn{2}{|c}{ 事前值に対する直後值の指数 } \\
\hline 被検者 & 1 回目 & 2 回目 \\
\hline A & 119.2 & 112.0 \\
\hline B & 85.7 & 84.2 \\
\hline C & 100.1 & 105.6 \\
\hline D & 147.6 & 143.9 \\
\hline E & 116.9 & 125.2 \\
\hline 計 & 569.5 & 570.9 \\
\hline 平均 & 113.9 & 114.2 \\
\hline 相関 & $\mathbf{r}=0.961$ \\
\hline
\end{tabular}

投影されるランドルト環の方向を，時計の短針に 諳み替える精神作業）を 5 名の大学生（21〜22 歳）に対して 9 分間負荷する実験を，昭和 50 年 10 月に 2 日にわたって行った。

結果および考家この結果, 表 6 の成績を得た。 すなわち, 事前值に対する事後值の增減率を指数 化した個人の測定值をみると，1回目と 2 回目と の間にあまり差がみられず，両者には高い相関 （r=0.961）が認められた。このことから，本検 査法には再現性があるるのと考える, な拉, 被検 者 5 名の指数の開きは, 精神作業負荷による影響 の個人差を示すものと考えられ，このことから， 精神作業適性を知ることの可能性が 示唆された。

\section{5. 括}

運動や精神作業を負荷して，事前と事後の測定 值から心身機能の低下度を測定せんとする試みは 数多く行われているが，従来行われてきた多くの 㭘查法は，負荷によって心身に疲労を自覚して も, 作業量や生理機能が必ずしも変化するとは限 らなかった。占)

このよ5に，自覚症状はあっても生理機能の変 化として捉えにくいのは，従来の検査法が機能を static にみよ5とするため，測定時には調節や適 忘により機能の変化が覆い隠され，あるいは，機 能の動的変化が測定值のバラッキを大きくする, などによるものと考学る，そこで筆者は，披労時 や飲酒時，あるいは身体的，精神的にその作業に 不適性な者ほど，負荷の影響が大きく，元の機能 に回復するまでの時間が長いことから，一挙に畩 境を変化させてこれに順応するまでの機能を時間 的に調べることができれば，調節や適応による影 響を受けないので，心身機能の低下度が測定でき るのではないかと考皇た。 そして，初期暗順忘， 調節，反応などの機能を含む暗順応初期の視認時 間から，生体の機能を dynamic に捉えようとす る視認時間測定器を試作した。

本測定器を用いて行ったいくつかの基礎実験成 樍は，大約次のとおりである。

(1)暗順応初期の視認時間正常值は，大学生男子 $(\mathrm{N}=37)$ が平均 2.554 秒，女子 $(\mathrm{N}=115) 2.643$ 秒で，両者に有意な差は認められなかった。 
(2)視認時間に含まれる要素について，可能な範 囲で所要時間を測定した結果，反応時間が最も短 く, 次いで初期暗順応時間, 調節時間の順に長い 時間を要した。これら要素別所要時間の長さや割 合は，視標の大きさによって変化することが恋め られたが，照度や負荷の違いが影響することも考 えられる。

(3)視標の大きさと視認時間の関係を, 大学生 12 名に対して測定した实験では，視標が小さくなる ほど視認時間が顕著に遅延することが確められ た。

(4)前照射舆境と視認時間との関係をみると，大 学生 4 名に対して高照度照明の曝露時間と視認時 間との関係を調べた実験では，高照度曝露時間が 長いはど視認時間が延長することが確められた。

また，室外環境照度と視認時間との関係を大学生 3 名に対して測定した実験では，環境琞度が明る いほど，実験室照度にすどした值後の視認時閆は 延長ナるが，10分後にはほぼ事前值に近づくこと が確められた。

(5)本实験の再現性をみるため，大学生 5 名に対 して, auto slideにより投影されるランドルト環 の约在時涪の短針に読み替える精神作業を9 分

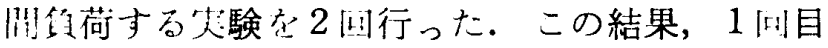
亡2 叫目の視铝咕間には，非常に高い相関が認め られたので，本検查法には再現性があるものと考 党学。

本検枯け，高照度環境から一挙に低照度環境に 变えたとき，予め測定した個人の夜間視力に応じ こ呈示される低照度視標を明視するるずの視慧㭙 泊在测定し，負荷後の機能変化の状態を量的に捉 占上 5 とする波学検查である。

本㭘直法は，測定の性質と1 以の测定時間の長 㤐の点から，被検者の意志が介入しにくく，視力 に灾じて視慧咕閆が正確に测定できる。また，初 期暗順応や調節力，おるいは反応時間などを含む 視認時間は，練習によってそれほど速まるもので はないから，熟練者に適するだけでなく，初めて
の被検者にも，2３分の練習を含めて，入空10 分後には測定できるなどの特幑がある.

本測定器により，視認時間の遅れから体力を評 価し，身体疲労や精神疲労定判定し，古るいは身 体的・精神的作業適性夌知ることの仃能性が手測 されたがここれらについての詳細は別に報告与 る.

なお，本研究の要旨は，第19间日本学校保健学 会 (1972), 第 8 [1] 日本アルコール矤学会(1973), 第39[门1日本民族衛生学会（1974）で発表した。

稿を終えるにあたり, 昭昭44年以来，当研究宗 に所属して多大の御協力をいただいた各年次の卒 業生諸君に対し，樑甚の謝意を吕上げる。

\section{引用文献}

1）藤井真美・寺田光世：調節時間測定器の試作と基礎 実験, 学校保硉研究, 12(4): 187〜193, 1970.

2）藤井真美・阿部康博：初期暗順応時間法によるアル コール耐性の判定, アルコール研究, 8(3)：135〜137, 1973.

3）藤井真美: 疲学度及び酪唒度と初期暗順応時間, 第 19回日本学校保健学会講演集, 1972.

4）藤井真美: 初期暗順応時間法汇上る精神疲学の判 定, 第39回日本民族衛生学会総会講演要旨集, 1974 .

5）橋本邦衛 - 大島正光: 疲労判定の大めの機 能 検 查 法, 同文書院，12，1962.

6）石川道雄：疲労（I）定義と原因を主として，健康教 室303集, 東山書房, 29 30, 1976.

7）川烟愛義・村上長雄他：体力貺定と健康部断, 南江. 堂, 144, 167, 1969.

8）小野勝義他：眼科全書第 1 巻, 金原出版, 185 189, 1969.

9）大島正光：人間はなせ疲れるか，からだの科学:34, 日本評論社, 50〜 53， 1970.

10）大身正光: 疲労の研究, 同文書院, 10〜 13, 1960.

11）大島正光：環境生理学, 医歯薬出版, $23,1967$.

12）紊藤煡吉：前照射時間の影㸷，東北医学雑誌，17, $122,1934$. 